О. З. Фоменко, Г. О. Ушакова, С. Г. Пієржиновський

Дніпропетровський національний університет ім. Олеся Гончара

Університет м. Люнд, Швеція

\title{
РІВЕНЬ ГІАЛУРОНАТУ ТА ЗАГАЛЬНОЇ \\ ГІАЛУРОНАТ-ЗВ'ЯЗУВАЛЬНОЇ АКТИВНОСТІ БІЛКІВ ЗА УМОВ РОЗВИТКУ ЕКСПЕРИМЕНТАЛЬНОГО ХРОНІЧНОГО ГЕПАТИТУ $C$ ТА ЛІКУВАННЯ АЛЬФА-КЕТОГЛУТАРАТОМ
}

\begin{abstract}
Встановлено вірогідне збільшення концентрації гіалуронової кислоти у сироватці крові щурів при моделюванні хронічного гепатиту $C$. Проведено дослідження змін у абсолютній та відносній гіалуронат-зв'язувальній активності цитозольних білків мозочка та гіпокампа щурів за нормальних умов, при експериментальному хронічному гепатиті $C$ та дії альфа-кетоглутарату.
\end{abstract}

О. З. Фоменко, Г. А. Ушакова, С. Г. Пиержиновский

Днепропетровский национальный университет им. Олеся Гончара

Университет г. Люнд, Швеция

\section{УРОВЕНЬ ГИАЛУРОНАТА И ОБЩЕЙ ГИАЛУРОНАТ- СВЯЗЫВАЮЩЕЙ АКТИВНОСТИ БЕЛКОВ В УСЛОВИЯХ РАЗВИТИЯ ЭКСПЕРИМЕНТАЛЬНОГО ХРОНИЧЕСКОГО ГЕПАТИТА $C$ И ЛЕЧЕНИЯ АЛЬФА-КЕТОГЛУТАРАТОМ}

Установлено достоверное увеличение концентрации гиалуроновой кислоты в сыворотке крови крыс при моделировании хронического гепатита $C$. Проведены исследования изменений в абсолютной и относительной гиалуронат-связывающей активности цитозольных белков мозжечка и гипокампа крыс при нормальных условиях, при экспериментальном хроническом гепатите $C$ и действии альфа-кетоглутарата.

\author{
O. Z. Fomenko, G. A. Ushakova, S. G. Pierzynowski \\ Oles' Gonchar Dnipropetrovsk National University \\ Lund University, Sweden
}

\section{HYALURONATE AND TOTAL HYALURONATE-BINDING CAPACITY OF PROTEINS UNDER EXPERIMENTAL CHRONIC HEPATITIS $C$ AND TREATMENT WITH ALPHA-KETOGLUTARATE}

The increase of hyaluronic acid concentration in the blood serum of rats during modelling of chronic hepatitis $C$ is presented. The research of changes in the absolute and relative hyaluronate-binding activity of cytosolic proteins in the rats' cerebellum and hippocampus under normal condition, experimental chronic hepatitis $C$ and with the alfa-ketoglutarate treatment was carried out. 


\section{Вступ}

У процесі лікування багатьох хвороб важливе своєчасне й точне їх діагностування, але частина діагностичних методів продовжують бути небезпечними, такі як біопсія печінки. Тому сьогодення вимагає пошуку нових безпечних, неінвазивних методів раннього діагностування хвороб та їх лікування.

Біологічна роль глікозаміногліканів в організмі велика: вони беруть участь у здійсненні опорної функції, проникності клітинних мембран, змазуванні суглобових поверхонь, у процесах диференціювання та регенерації тканин, запліднення та розмноження, у водно-сольовому обміні між тканинами та міжклітинною рідиною, у здійсненні реакцій імунітету, у регуляції апоптичних реакцій $[1 ; 6]$. Сьогодні актуальним $\epsilon$ дослідження глікозаміногліканів не лише у сполучних тканинах, а й у мозку. Адже вони беруть активну участь у процесах нейрорегенерації, пластичності мозку, взаємодії 3 факторами росту, проліферації клітин.

Особливо цікавим останнім часом стало виявлення та дослідження ГАГ у мозку тварин і людини. У центральній нервовій системі протеоглікани - одні з головних молекул, що формують гематоенцифалічний бар'єр, впливають на структуру, розвиток і міграцію аксонів. Бічні ланцюги глікозаміногліканів часто формують гібридні ланцюги із сульфатованими гетеросахаридами та слугують нейрональними маркерами стовбурних клітин, нейрогенними та нервовостимулювальними молекулами, що відповідають за проліферацію клітин мозку. Гібридні ланцюги ГАГ включаються до формування нейронної мережі, захоплюючи зв'язані фактори росту. Дослідження клітин мозку показали істотну роль ПГ і ГАГ у різних біологічних процесах, включаючи цитокінез, проліферацію, диференціацію, міграцію, морфогенез тканини, органогенез, участь у формуванні відповіді на інфекцію й загоєння ран [3].

Оскільки суттєві порушення печінки супроводжуються розвитком енцефалопатії, метою даної роботи було визначення зміни загального рівня гіалуронової кислоти у сироватці крові щурів і загальної гіалуронат-зв'язувальної активності цитозольних білків мозку щурів при моделюванні хронічного гепатиту $C$ та застосуванні альфакетоглутарату.

\section{Матеріал і методи досліджень}

Для дослідження використовували мозок і сироватку крові 18 щурів лінії Вістар. Спосіб моделювання хронічного гепатиту $C$ [5] включав токсичне ушкодження гепатоцитів чотирихлористим вуглецем і формування аутоімунної відповіді: після триразового уведення чотирихлористого вуглецю дозою 0,25 мл $50 \%$ розчину в рафінованій олії тваринам уводили триразово гомогенат печінки з повним ад'ювантом Фрейнда дозою 0,5, 0,25, 0,25 мл через 15 і 9 діб, і дворазово у проміжках азатіоприн дозою 50 мг/кг. Тварини розділені на три групи $(n=6)$ : I - контрольна, II - моделювання хронічного гепатиту $C$, III - моделювання хронічного гепатиту C, а потім лікування альфа-кетоглутаратом 0,228 \% у питній воді протягом 10 діб. Тварин декапітували під легким наркозом із застосуванням ізуфурану. Концентрацію гіалуронової кислоти в сироватці крові визначали за допомогою методу Голда [2]. Загальну гіалуронатзв'язувальну активність білків у цитозольній фракції мозку проводили за допомогою твердофазного вуглевод-ферментного мікроаналізу [4]. Результати піддавали статистичній обробці з використанням критерію Стьюдента. 


\section{Результати й обговорення}

Вплив гепатиту $C$ призвів до зміни загального рівня гіалуронової кислоти у крові щурів (рис. 1). Порівняно з контролем, група тварин з експериментальним гепатитом $C$ мала приріст концентрації гіалуронату майже на 26 \%. При дії на хворих щурів альфакетоглутаратом спостерігається подальше підвищення рівня гіалуронової кислоти в сироватці (на $35 \%$ порівняно зі значеннями контрольної групи). Серед біологічно активних речовин природного походження особливе місце належить гіалуроновій кислоті (ГК), або гіалуронату - лінійному глікозаміноглікану, що не $\epsilon$ сульфатованим, складається з 2 000-25 000 дисахаридів глюкуронової кислоти та $N$-ацетилглюкозаміну, молекулярна маса цього полімеру - до 1000000 Да. Усередині мономеру - 1,3-бетаглікозидний зв'язок, між мономерами - 1,4-бета-глікозидний зв'язок. Незважаючи на простоту будови, ГК істотно відрізняється від інших глікозаміногліканів, за своїми розмірами, фізико-хімічними властивостями та особливостями синтезу. Гіалуронова кислота входить переважно до складу міжклітинної речовини, де іiі період напівіснування триває близько 8 годин. Ї̈̈ олігомери проникають у лімфатичні судини, потім у лімфатичні вузли, де й відбувається остаточне розщеплення ферментом гіалуронідазою, яка синтезується у печінці. Рівень гіалуронової кислоти у сироватці один із біохімічних маркерів, що характеризує розвиток фіброзу печінки за умов експериментального гепатиту $C$ (дані гістологічного дослідження печінки підтвердили наявність фіброзу печінки у дослідних тварин). Отримані дані свідчать про те, що монотерапія за участю альфа-кетоглутарата протягом 10 діб не викликає нормалізації рівня гіалуронової кислоти у крові.

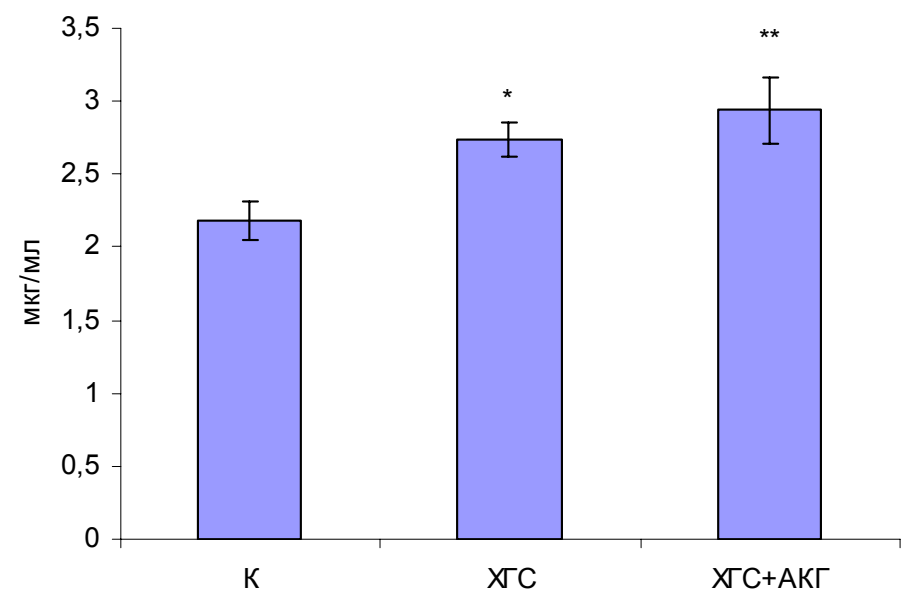

Рис. 1. Рівень гіалуронової кислоти в сироватці крові щурів:

$K$ - контрольна група, $Х Г C$ - моделювання хронічного гепатиту С, $X \Gamma C+A K \Gamma-$ група тварин, у яких моделювали гепатит $\mathrm{C}$, а потім лікували альфа-кетоглутаратом $(0,228 \%)$ протягом 10 діб; $n=6,{ }^{*}-p<0,05, * *-p<0,01$

Дослідження гіалуронат-зв'язувальної активності білків у різних відділах мозку щурів показали, що при захворюванні гепатитом $C$ достовірно не змінюється абсолютна кількість активних до зв'язування з гіалуронатом білків (рис. 2), але значно знижується їх відносна активність (у співвідношенні із загальною кількістю білків). Це може бути наслідком того, що при розвитку хронічного гепатиту в мозку дослідних щурів збільшується кількість неспецифічних до глікозаміногліканів білків. Застосування альфа-кетоглутарату призводить до зниження гіалуронат-зв'язувальної активності білків у 
мозочку (на 50 \% відносно значень групи з моделюванням ХГС), але достовірно не змінює іï у гіпокампі. Відносна активність гіалуронат-зв'язувальних білків при застосуванні альфа-кетоглутарату нормалізувалась, зростаючи у напрямку контрольних значень. Як відомо, гіалуронат-зв'язувальні білки, зв'язуючись із гіалуроновою кислотою, впливають на рухливість клітин і клітинну адгезію. Таким чином, відновлення нормальних значень відносної гіалуронат-зв'язувальної активності свідчить про позитивний вплив альфа-кетоглутарату на гіалуронат-залежну сигнальну систему.

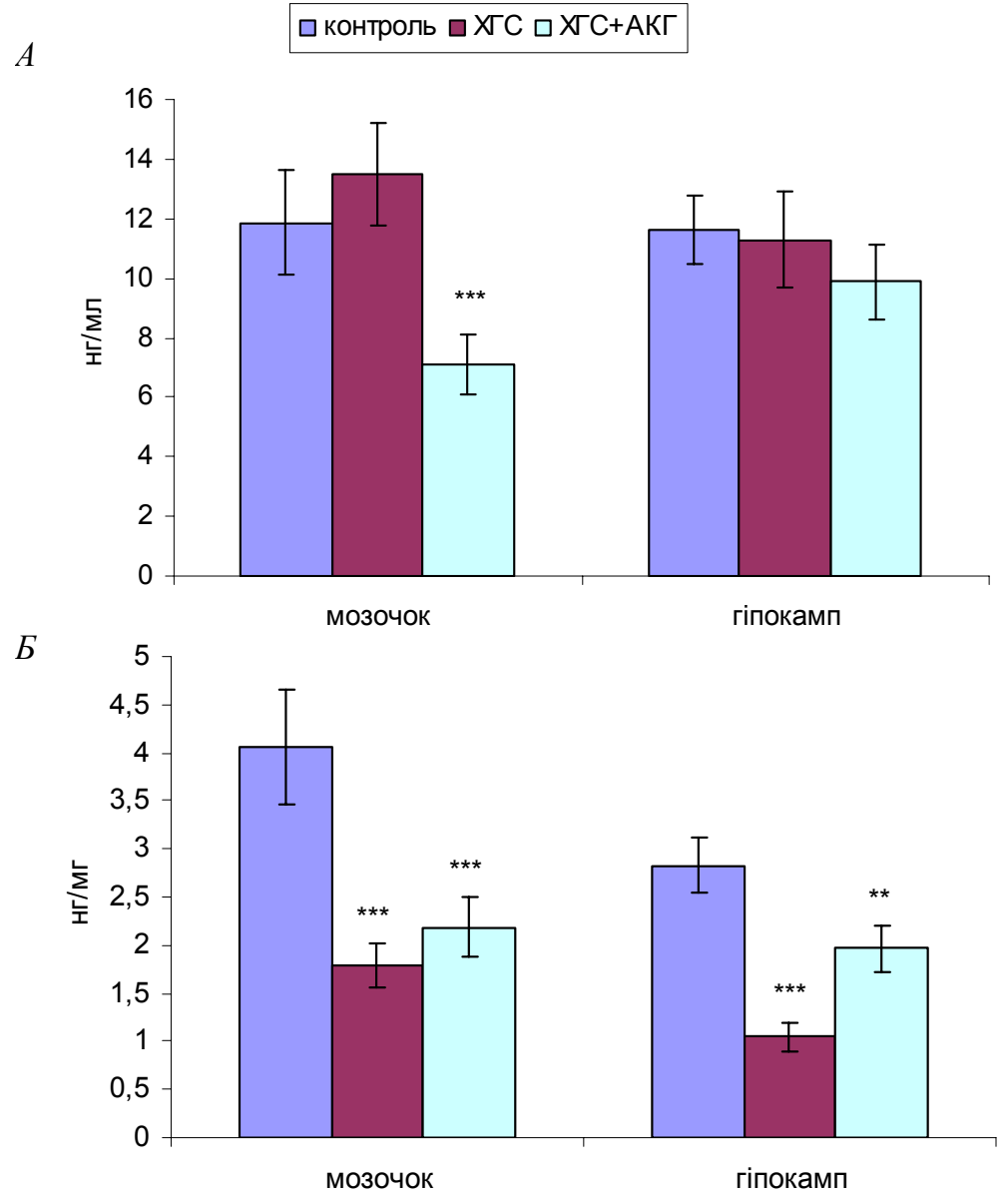

Рис. 2. Абсолютна $(A)$ та відносна $($ ( $)$ гіалуронат-зв'язувальна активність цитозольних білків мозочка та гіпокампа щурів: $K$ - контрольна група, $X \Gamma C$ - група 3 моделюванням хронічного гепатиту $C, X \Gamma C+A K \Gamma$ - група тварин, у яких моделювали гепатит $C$, а потім лікували альфа-кетоглутаратом $(0,228 \%)$ протягом 10 діб; $n=6,{ }^{* *}-p<0,01, * * *-p<0,001$.

Розвиток ПЕ пов’язується з нейротоксичними метаболітами, що здатні проходити крізь гемато-енцефалічний бар'єр. Об'єкт дії цих токсичних метаболітів - астроглія ЦНС (місце синтезу гіалуронату), котра відіграє принципову роль у трофіці нейронів і процесах нейротрансмісії [7; 8]. Серед нейрогенних токсинів найбілыш значиму роль відводять аміаку. Його рівень у крові підвищений у 90 \% хворих цирозами печінки та ПЕ, а його вміст у головному мозку також збільшений. У головному мозку цикл сечовини не функціонує, тому видалення 3 нього аміаку проходить різними шляхами, більшістю за рахунок глутамат-глутамінного циклу. Робота цього механізму відбувається за прямою участю альфа-кетоглутарату, котрий вилучається 3 циклу 
Кребса [9; 10]. Терапевтичне надходження альфа-кетоглутарату запобігає розвитку гіпоенергетичного стану в ЦНС та прискорює процес детоксикації аміаку в мозку, що покращує метаболізм білків та гіалуронат-зв'язувальних у тому числі.

\section{Висновок}

Підвищений рівень гіалуронової кислоти у сироватці крові може бути використаний як непрямий неінвазивний діагностичний показник рівня запалення та фіброзу печінки при гепатиті $C$. Експериментальний гепатит $C$ не викликає зміни центрів зв'язування гіалуронату у мозку дослідних тварин, але характеризується зниженням відносної гіалуронатзв'язувальної активності цитозольних білків мозочка та гіпокампа щурів. Застосування альфа-кетоглутарату 0,228 \% у питній воді протягом 10 діб нормалізує обмін гіалуронату та специфічних рецепторів у мозку порівняно з хворими тваринами за рахунок збільшення швидкості детоксикації, але не зупиняє розвиток фіброзу печінки.

\section{Бібліографічні посилання}

1. Gandhi N. S. The structure of glycosaminoglycans and their interactions with proteins / N. S. Gandhi, R. L. Mancera // Chem. Biol. Drug. Des. - 2008. - Vol. 72, N 6. - P. 455-482.

2. Gold E. W. The quantitative spectrophotometric estimation of total sulfated glycosaminoglican levels // Biochemica et Biophysica Acta. - 1981. - Vol. 673. - P. 408-415.

3. Takashi Y., Rumi T., Toshie T. The effect of sulfated hyaluronan on the morphological transformation and activity of cultured human astrocytes / Y. Takashi, T. Rumi, T. Toshie / Biomaterials. - 2008. - Vol. 29. - P. 3503-3513.

4. Ushakova G. Postnatal dynamics of the heparin-binding activity of rat cerebellar cells // Нейрофизиология / Neurophysiology. - 1999. - Vol. 31, N 2. - P. 140-141.

5. Пат. 15752 Україна, МПК G 09 В 23/28. Спосіб моделювання хронічного гепатиту $C /$ В. Ю. Ніколенко, Ю. І. Ніколенко, О. Ю. Ніколенко; заявник та власник Донецький гос. мед. ун-т. - № u2006004614 заявл. 18.01.2006; набрано чинності 17.07.2006.

6. Ушакова Г. О. Роль глікозаміноглікан-зв'язуючих білків у морфогенезі та пластичності мозку. Автореф. дис. ... д-ра біол. наук: Харк. нац. ун-т ім. В. Н. Каразіна. - Х., 2005. - 35 с.

7. Sheline C. T. Free radical-mediated neurotoxicity may be caused by inhibition of mitochondrial dehydrogenases in vitro and in vivo / C. T. Sheline, L. Wei // Neuroscience. - 2006. - Vol. 140, N 1. - P. 235-246.

8. The role of astrocytes and complement system in neural plasticity. / M. Pekny, U. Wilhelmsson, Y. R. Bogestal, M. Pekna // Int. Rev. Neurobiol. - 2007. - Vol. 82. - P. 95-111.

9. 2-Oxoglutarate downregulates expression of vascular endothelial growth factor and erythropoietin through decreasing hypoxia-inducible factor-1alpha and inhibits angiogenesis / K. Matsumoto, S. Imagawa, N. Obara et al. // J. Cell. Physiol. - 2006. - Vol. 209, N 2. - P. 333-340.

10. Dakshayani K. B. Alpha-ketoglutarate modulates the circadian patterns of lipid peroxidation and antioxidant status during $N$-nitrosodiethylamine-induced hepatocarcinogenesis in rats / K. B. Dakshayani, P. Subramanian // J. Med. Food. - 2006. - Vol. 9, N 1. - P. 90-97.

Надійшла до редколегї̈ 04.06.2010 